\title{
Die invloed van sekularisasie op die NG Kerk: 'n kerkhistories-sosiologiese perspektief
}

\author{
NGTT DEEL 55, NR 3 \& 4, 2014
}

\section{Kruger, Pieter}

Universiteit van Pretoria

Van der Merwe, Johan

Universiteit van Pretoria

\section{ABSTRACT}

\section{The influence of secularisation on the DR Church: A church histori-} cal and sociological perspective

The influence of religious discourses and institutions in South Africa, as elsewhere, diminishes because of structural secularisation. Social secularisation as another form of secularisation compromises the 'necessity' for religion in modern day social culture. Humanistic Western Individualism is the dominant social meaning system (also in South Africa) best associated with this process. The actualisation of its priorities (personal freedom, privacy, emancipation of the self, freedom of choice and to strive for personal affluence) plays a significant role in the lives of the Dutch Reformed Church's congregants. Social secularisation liberates people from ecclesiastical doctrine as regulatory for personal life and reason and marks the growing indifference to the official church. This leads to a legitimacy crisis concerning established religious meaning systems. Ironically religion doesn't disappear altogether because of secularisation. It does however, transposes traditional forms of collective religion because the sustainment of religion as phenomenon depends increasingly on religiosities in the private sphere. Consequently, the proliferation of different personal, religious beliefs and practices also increases religious pluralism within the Dutch Reformed Church, challenging its reformed identity.

\section{TREFWOORDE}

Sosiale konstruksie, Religieuse konstruksie, Strukturele sekularisasie, Sekularisering van sosiale kultuur, Sekularisering van persoonlike bewussyn, Privatisering van religie, Omvorming van religie

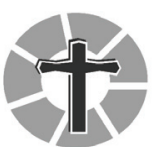




\section{KEYWORDS}

Social construction, Structural secularization, Religious construction, Secularization of social culture, Secularization of personal, Privatization of religion, Transposition of religion

\section{KONTAKBESONDERHEDE}

Dr Pieter Kruger

PO Box 570, NIGEL, 1490

pkkruger@telkomsa.net

Prof Johan van der Merwe

Fakulteit Teologie, Universiteit van Pretoria

Pretoria, 0002

johan.vdmerwe@up.ac.za 


\section{INLEIDING}

Sekularisasie het by wyse van sosiaal-strukturele prosesse asook as sosiologiese verskynsel 'n onafskeidbare deel van die hedendaagse lewensfilosofie geword. Buiten 'n verduideliking van wat sekularisasie as verskynsel behels, word in hierdie artikel aangetoon hoe sekularisasie godsdiens en die kerk se plek binne die Suid-Afrikaanse samelewing verander, hoe dit die waarde van godsdienstige opvattings sosiaal laat verminder, hoe dit godsdiens toenemend 'n private aangeleentheid laat word en hoe dit die NG Kerk as instelling omvorm. Dit word ondersteun deur resultate van empiriese navorsing wat binne die NG Kerk onderneem is. In die bespreking van die uitdagings waarvoor die NG Kerk te staan kom, word rigtingwysers aangedui waarmee die kerk op weg moet gaan te midde van die verbreiding van sekularisasie.

\section{DIE SAMELEWING WAARVAN DIE NEDERDUITSE GEREFORMEERDE KERK'n DEEL IS}

Om te verstaan hoe sekularisasie as samelewingsverskynsel die NG Kerk beïnvloed, moet die sosiale konstrukte van die Suid-Afrikaanse samelewing waarbinne die NG Kerk met sy eiesoortige religieuse konstrukte bestaan, ondersoek word.

\subsection{Die samelewing as sosiale konstruksie}

Enige samelewing is die produk van menslike interaksies wat terugwerkend die mense in daardie samelewing affekteer (Berger, 1990:15). Die identiteit wat 'n persoon kognitief sowel as normatief bekom en handhaaf, word bepaal deur die sosiale instellings wat binne die samelewing se openbare politieke, ekonomiese en burgerlike sfere funksioneer (Koopman, 2003:9-10). Dekker (1997:53) beskryf dié relasie tussen 'n individu en die samelewing as 'n dialektiese relasie. Empiries word waargeneem dat die samelewing en sy instellings voortdurend verander (Berger, 1990:36). In die proses word die kollektiewe sosiale konstruksies waarmee individue identifiseer, dekonstrueer en tree nuwe sosiale konstruksies na vore wat die aard van 'n bepaalde samelewing kan omskep.

\subsubsection{Die sosiale konstrukte wat in die Suid-Afrikaanse samelewing verteenwoordig is}

In die Suid-Afrikaanse samelewing word drie prominente sosiale konstrukte aangetref wat weens bepaalde prosesse van sosiale konstruksie as "samelewingsvisies" dien. Van der Walt (1999:25-26) verwys na die ou apartheidskollektivisme, Afrikakommunalisme en Westerse individualisme.

Die apartheidskollektivisme is met beleid vir byna vyftig jaar in Suid-Afrika gehandhaaf. Die samelewing is in homogene rasse met geslote samelewingsinstellings 
ingedeel. In hierdie tyd is die kulturele eenheid van die Afrikanernasie bevorder en het Afrikaner-individue vrye selfontplooiing en ekonomiese opbloei in verbondenheid aan die Afrikanervolk beleef. Die ironie was dat die groot Afrikanermiddestand wat sodoende ontstaan het se nasionalistiese bewussyn stelselmatig begin kwyn het en dat hulle sterk met die prioriteite van Westerse Individualisme begin identifiseer het (Grundlingh, 2001:250). Die einde van apartheid het die groot Afrikaner-middestand se lewensfokus nog meer laat verskuif na materialisme en 'n meelopende verbruikersmentaliteit (Czeglédy, 2008:289).

- Die sosiale verandering sedert die African National Congress se bewindsaanvaarding in 1994 het Afrika-kommunalisme as samelewingsvisie met 'n outentieke Afrika-geörienteerde denk- en waardesisteem na vore laat tree. Die apartheidsdiskoers se negatiewe uitwerking op die swart bewussyn het hierna tot die oorweldigende beklemtoning van hierdie Afrika-identiteit gelei (Du Toit, 1999:6,8). Ten spyte van die gedemokratiseerde Suid-Afrika se probleme bly Afrika-kommunalisme 'n simbool van hoop vir baie wat daarmee identifiseer. Vir dié wat geensins daarmee identifiseer nie, word dit toenemend 'n simbool van wanhoop (Du Toit, 1999:5). Baie Afrikaners beleef volgens De Klerk en Van Helden (2011:8) dat hulle sosiaal op die periferie van die samelewing bestaan. Dit bring identiteitsverlies en negativisme wat daartoe lei dat algemene kritiek teenoor die landsregering en die sosiale situasie tans, geredelik uitgespreek word.

- Aangesien die Afrikaner se apartheidsidees sosiaal afgetakel is en hulle nie sondermeer met Afrikakommunalisme as samelewingsvisie identifiseer nie, tree Westerse individualisme as denksisteem vanuit die Westerse wêreld in die lewe van hedendaagse Afrikaners na vore. Volgens Durand (2002:58-59) is dit veral opmerklik onder tweede-geslag en derde-geslag Afrikaners (wat volwassenheid bereik het teen die einde van die apartheidsera en daarna). Moderne Afrikaners ag hulleself toenemend as onafhanklike individue by wie 'n tipe solipsisme ontwikkel waardeur sosiale instellings se invloed in hulle lewe verminder en gerelativeer word. Sosiale meelewing verkry 'n kontraktuele karakter en so verander hulle verhouding ook met die geïnstitusionaliseerde kerk. Hulle het 'n pragmatistiese lewenshouding en reflekteer daarom (in 'n pluralistiese samelewing soos Suid-Afrika) op hulle eie tradisies asook ander maniere van dink en doen wat teenwoordig is (Durand, 2002:30). Daarom vind ons dat die meeste Afrikaners die multi-kulturele identiteit van Suid-Afrika tog geredelik aanvaar en daarby aanpas deur 'n nuwe identiteit as persoon te ontwikkel wat nie noodwendig sosiaal verkry is nie. 


\subsection{Godsdiens as sosiale konstruksie}

In sosiologiese sin word godsdiens ook as 'n menslike onderneming beskou waardeur 'n sosiale opset asook 'n transendente opset tot stand gebring word. Soos ander sosiale instellings struktureer godsdiens mense se aktiwiteite deurdat sekere oortuigings, waardes en georganiseerde godsdienspraktyke kollektief gevestig word (Berger, 1990:25). Die mate waarin individue met die religieuse groep se kollektiewe oortuigings identifiseer, beïnvloed die gemeenskap van gelowiges se volhoubaarheid asook die individu se belewenis van geborgenheid op kognitiewe en normatiewe vlak (McGuire, 1991:36,37).

Histories het godsdienstige beskouings met sosiale lewensbeskouings in die gemeenskappe waarin dit gefunksioneer het, saamgeval. Die burgerlike godsdiens wat sodoende ontwikkel het (Johnstone, 1988:74), het veroorsaak dat die godsdienstige kultuur moeilik van die politieke kultuur of die intellektuele kultuur onderskei kon word (Martin, 2005:55). Toenemende pluralisasie in moderne samelewings ondermyn die instandhouding van sodanige godsdienstige betekenissisteme op kollektiewe vlak. Daarom kom religieuse differensiasie en die vermenigvuldiging van verskillende godsdienstige groeperinge of denominasies waarin subjektiewe werkinge te vinde is, voor (Maclure \& Taylor, 2011:72). Hierdie werkinge hou verband met die individuele vlak van godsdiens waar die gelowige individue se subjektiewe, godsdienstige belewenisse en oortuigings 'n belangrike invloed in geïnstitusionaliseerde religie word.

\subsubsection{Die religieuse konstrukte van die NG Kerk}

Die tydsgees se sosiale konstrukte vind neerslag in die kerk se religieuse konstrukte. Histories en sosiologies kan die invloed daarvan in 'n mindere of meerdere mate ook in die NG Kerk raakgesien word.

Histories het die NG Kerk ook 'n burgerlike godsdiens beoefen wat in essensie 'n sosiale godsdiens was waarin die Afrikaner se nasionalistiese aspirasies gedien is. Wat aanvanklik begin het as die NG Kerk se konkrete, pastorale sorg aan die Afrikaner na die Tweede Vryheidsoorlog (Olivier, 2002:158) het ontwikkel tot die apartheidsteologie wat as religieuse konstruk met die Afrikaner se verstaan van sy rasseverhoudinge verband gehou het (Kinghorn, 1986:117). Hoewel die NG Kerk die apartheidsteologie afgelê het en moderne Afrikaners (as lidmate van die NG Kerk) nie meer hierdie religieuse konstruk handhaaf nie, meen die skrywer het iets van dié kollektiviserende kyk tog oorgebly. Verder is dit steeds Afrikaners wat solidariteit met die NG Kerk soek. 
- Die gereformeerde identiteit van die NG Kerk omvat belangrike religieuse konstrukte. Gereformeerdheid as kerkbeweging se sentrale religieuse motiewe sluit die volgende in (Burger, 2001:48 [met verwysing na Brian Gerrish]):

- 'n Lewe voor die aangesig van God waarin God sentraal gestel word in die geestelike lewe van gelowiges en die kerklike lewe;

- Die gebondenheid aan die Woord as gesagvol vir die lewe in totaliteit;

o 'n Gerigtheid op die lewe wat die kerk uitdaag om die kompleksiteit van die lewe te verstaan en daarby betrokke te wees.

Die NG Kerk se gereformeerdheid bevat ook evangeliese trekke (as gevolg van evangeliese invloede) wat volgens Balcomb (2001:4) in die volgende sigbaar is: die nodigheid van 'n lewensverandering; die aanwakkering van missionêre pogings; die absolute gesag van die Bybel vir die lewe; die sentraliteit van Christus se kruis.

- By die sitting van die NG Sinode Hoëveld in 2012 sit sinodegangers sake op die tafel waaroor hulle verontrus is: die invloed van die inligtingsontploffing op lidmate; die "Google"-generasie wat alles bevraagteken; lidmate se geestelike onvolwassenheid; die populariteit van "sagteband"-teologie; die toenemende ondermyning van geloofswaarhede; die kerk wat nie meer duidelike etiese uitsprake lewer nie (Handelinge van die NG Sinode Hoëveld, 2012:36-37). Hierdie sake is kontoerlyne van dieperliggende kwessies en hedendaagse paradigmas wat op die kerk inspeel.

Hierdie sake hou verband met die invloed van wêreldwye prosesse van kulturele, sosiale, politieke, ekonomiese en tegnologiese transformasie (Smit, 2001:120). SuidAfrika is nie hiervan uitgesluit nie. Transformasieprosesse op vele terreine binne die Suid-Afrikaanse samelewinghet dieNGKerkseprominente posisiein die samelewing, saam met Christelike oortuigings in die algemeen, dramaties verander (Schreuder, 2002:226). Die kerk is nie meer die beskermer van etiese waardes nie omdat mense deesdae pragmaties dink en optree. Moraliteit staan al meer los van religie (Durand, 2002:56). Hierdie subjektiewe pragmatisme beïnvloed ook die kerk se konfessionele karakter deurdat dit beland in die sleurkrag van persoonlike oortuigings. Buiten die gereformeerde spiritualiteit wat die Calvinistiese tradisie van die NG Kerk handhaaf en die rasionalistiese beweging met sy sterk kognitiewe aspek, wys Steyn (2006:1-13) daarop dat andersoortige spiritualiteite toenemend in die NG Kerk aangetref word: die charismatiese wat 'n beweging na 'n gevoelsmatige godsdiensbelewenis aandui, die mistieke spiritualiteit wat introverties en kontemplatief is en die sinkretistiese beweging wat die groeiende selfhelp-godsdienservaring verteenwoordig. Dié skuiwe word aangebring deur lidmate se behoefte aan 'n direkte godsdienstige belewenis 
wat 'n tipe kommodifisering van die godsdiens kan meebring. Die godsdienstige praktyk word dan gemoduleer volgens die patroon van ander instellings wat goedere en dienste moet lewer in 'n kompeterende mark (Turner, 2011:150). Hierdie toedrag word verskerp deur 'n pluralistiese sosiale omgewing waar verskillende sosiale en religieuse oortuigings (soos in Suid-Afrika) bestaansreg het en op gelyke vlak vir 'aanhangers' kompeteer. Pluralisme in 'n samelewing bemoeilik die instandhouding van godsdienstige betekenissisteme op kollektiewe vlak. Pluralisme bring relativisme as vrug voort. Die implikasie daarvan vir die konsep 'waarheid' is dat dit bloot as 'n konstruksie beskou word en nie ontologies van aard is nie (Durand, 2002:27). Daarom word daar wegbeweeg van vaste antwoorde en veroorloof mense hulle die vryheid om hulle eie opinies te lig omtrent die tradisionele, geldende geloofswaarhede (Hofmeyr, 2002:12-13). Dit is die tendense wat onderliggend is aan die sake wat op die NG Kerk se tafel beland het. Die historie hiervan is ontwikkelend en daarom is die NG Kerk binne die hedendaagse sosiale en religieuse konteks in transito na nuwe religieuse konstrukte waarvan die uitkomste nog nie duidelik is nie. Die veranderings wat die NG Kerk beleef, kan egter daartoe lei dat lidmate vervreem voel. Op individuele vlak asook binne die kerk kan 'n gevoel van anomie ontstaan, aangesien die bekende normatiewe riglyne en religieuse oortuigings deur verandering in gedrang kom (McGuire, 1991:34). Weerstand teen verandering kan ontstaan weens 'n inherente, konserwatiewe element wat'n gegewe religieuse tradisie wil kontinueer (McGuire, 1991:213), of omdat individue hulle "eie-belang" binne daardie instelling wil "bewaar" (Esterhuyse, 2001:194).

\section{SEKULARISASIE AS SAMELEWINGSFENOMEEN}

Sekularisasie hou verband met die sosiale verskynsel waarin 'n sosiale orde verwyder raak van godsdienstige idees se invloed (Turner, 2011:128). In antikerklike kringe verwys sekularisasie na die moderne mens se vrywording van godsdienstige voogdyskap in die daaglikse lewe en die veronderstelling dat die lewe deur alledaagse, sekulêre middele soos die moderne wetenskap genoegsaam verbeter en in stand gehou kan word. In tradisionele kerklike kringe word dit verklaar as "ont-Christeliking" (Berger, 1990:106-107). Sekularisasie het direkte implikasies vir religieuse realiteite en konstrukte (Cady \& Hurd, 2010:4) op 'n publieke vlak sowel as in die private sfeer van mense se daaglikse bestaan. Op die publieke vlak vind ons strukturele sekularisasie wat te doen het met sosiaal-strukturele ontwikkelings soos die staat wat van die kerk se invloed geskei word en sy neutraliteit ten opsigte van godsdiens as sosiale rolspeler handhaaf (Maclure \& Taylor, 2011:34). Dit gebeur ook met ander strukture waarin ons leef (wetenskaplik, sosiaal, tegnologies, opvoedkundig en so meer) dat elkeen in sy eie terme verstaan word sonder verwysing 
na die 'transendente' (Taylor, 2007:594). Hierdie moderne differensiasieproses dra daartoe by dat die kerklike lewe toenemend van die wyer samelewing afgesluit word (Dekker, 1997:141). Sodoende word godsdiens se sosiale invloed gemarginaliseer en speel die kerk geen determinerende rol in die samelewing nie. Waar die kerk wel nog 'n sentrale posisie behou, is dit dikwels slegs simbolies van aard (Avis, 2003:80). Nog 'n proses, sosiale sekularisasie, verteenwoordig 'n sosiologiese verskynsel wat in twee dimensies merkbaar is: die sekularisering van die openbare kultuur en die sekularisering van die persoonlike bewussyn (Maclure \& Taylor, 2011:21). Op 'n openbare vlak verminder die sosiale betekenis van godsdiens, asook die effek daarvan op openbare opinies en sosiale norms (Avis, 2003:52). Op private vlak verminder sekularisasie mense se godsdienstigheid omdat die mens hom vry ag van 'n ander, metafisiese wêreld se invloed (Dekker, 1997:133). Dié interne sekularisasie maak die toekoms vir die individu oop en laat hom op selfaktualisering as 'n lewensprioriteit fokus (Degenaar, 1974:51). Daarom neem die singewende invloed van godsdiens in mense se lewens af en steur hulle, hulle al minder aan kerklike voorskrifte. Niemandt (2013b:9) meen dat Suid-Afrika 'n soort gekonsentreerde sekularisasie beleef waar al hoe meer mense al minder waarde aan godsdiens heg en bewustelik 'n keuse uitoefen om nie in 'n god te glo nie. Die offisiële, geïnstitusionaliseerde godsdiens word deur hierdie ontwikkelings geraak en is met min keuse gelaat om by die veranderende denkbeelde en denkwyses van mense aan te pas. Dít is nie bevorderlik vir die instandhouding van tradisioneel-ortodokse leerstellings en praktyke nie (Dekker, 1997:145,147). Sekularisasie is 'n proses wat deur sosiale en institusionele veranderings opgemaak word en geleidelik 'n heroriëntasie tot die lewe meebring wat op geen sistematiese wyse teengestaan word nie (Norman, 2003:50).

\subsection{Die oorsake van sekularisasie}

Die draers van sekularisasie word vervolgens bespreek:

- Moderniteit en postmoderniteit

Avis (2003:52,65) meen dat sekularisasie te doen het met die opkoms die periode-konsepte, moderniteit en postmoderniteit. Modernisme en postmodernisme as gelyklopende filosofiese lewensbeskouings laat die klem val op dié sekerheid dat die mens die kenbare sosiale orde (ekonomies, polities, tegnologies) kan verander en beheer volgens universeel-rasionele kriteria wat in die mens self gesetel is (Avis, 2003:92-93). Dit stel die mens in staat om 'n ongebonde, selfstandige individu met sy of haar eie opinies te wees (Gergen, 1991:7). Dit verklaar die hedendaagse klem op 'n selfaktualiseringservaring (Avis, 2003:87). Groot kollektiewe magte soos die kerk, verloor op hierdie wyse hulle mag in die individu se lewe. Dit het 'n kragtige sekulariserende effek op 
die individuele bewussyn, aangesien die aanspraak wat godsdiens normaalweg op die lewe van mense gehad het deur rasionalisme gedekonstrueer word.

\section{- Institusionele differensiasie}

Aangesien die moderne ekonomiese, politieke, tegnologiese en opvoedkundige sfere volgens hulle eiesoortige rasionaliteit funksioneer, is institusionele differensiasie met gespesialiseerde funksies 'n gegewe (McGuire, 1991:233234). Die gevolglike vorming van die Christelike kerk as sosiale instelling het onopsetlik bygedra tot sosiale sekularisasie, want die konsentrasie van godsdienstige aktiwiteite en simbole in een institusionele sfeer veroorsaak dat dit van die res van die samelewing en sy sosiale instellings verwyder raak (Berger, 1990:123). So verminder die offisiële kerk se vermoë om op direkte wyse die samelewing te impakteer. Die kerk het deesdae 'n gemarginaliseerde getuienis wat dikwels ontledig is aan dogmatiese inhoud en 'n eenvoudiger, etiese vorm verteenwoordig (Norman, 2003:13,15).

\section{- Liberale politiek}

Hedendaagse liberale demokrasieë is institusioneel verwyder van godsdienstige instellings en -oortuigings (Berger, 1990:130). Dit staan neutraal teenoor verskillende godsdienste en hulle morele perspektiewe en daarom vind geen direkte godsdienstige invloed in staatkundige beleidvorming plaas nie (Avis, 2003:9). In 'n gesekulariseerde politieke opset bestaan die kerk onder 'n "regime of secularism" (Maclure \& Taylor, 2011:9). Suid-Afrika is 'n sprekende voorbeeld hiervan, hoewel godsdienstige fondasies in die samelewing nie geheel en al met 'n allesomvattende sekulêre filosofie vervang is nie.

\section{- Industriële kapitalisme en globalisasie}

Die moderne ekonomie met die globale, industriële kapitalisme as dinamiese faktor is 'n belangrike draer van sekularisasie, aangesien die ideologiese beginsels daarvan vry van godsdiens is (Berger, 1990:109). Daarby bevat die opleiding van die moderne industrie se personeel rasionele wetenskaplikeen tegnologiese beginsels wat 'n direkte sekulariserende invloed op die struktuur en funksionering van die industrie het (Berger, 1990:132). Verder skep die globale, kapitalistiese ekonomieë'n verbruikersekonomie wat gedryf word deur onmiddellike verbruikersatisfaksie - 'n mentaliteit wat nie gerat is vir godsdienstige oortuigings van tevredenheid, dankbaarheid en eenvoud nie (Avis, 2003:85). Toenemende globalisering veroorsaak dat nasionale gemeenskappe wêreldwyd deur die sekulariserende effek van hierdie ekonomiese sisteem beïnvloed word (Berger, 1990:130). 


\section{- Menslike sekuriteit}

Wetenskaplik-tegnologiese ontwikkelings verhoog die vlakke van menslike sekuriteit (Norris \& Ingelhart, 2004:19). Waar die ervaring van hierdie sekuriteit laag is, sal die belangrikheid van godsdienstige waardes verhoog en vice versa. Menslike ontwikkeling en 'n samelewing in transisie na 'n industriële ekonomie verhoog die ervaring van sekuriteit en verminder die belangrikheid van godsdienstige praktyke en waardes. Die ervaring van menslike sekuriteit werk dus sekularisasie mee en verklaar volgens Norris en Ingelhart (2004:217) hoekom ryk en arm lande van mekaar verskil ten opsigte van hulle waardesisteme en die rol wat godsdiens speel.

\section{- Protestantisme}

Moltmann (1999:91) meen dat die Westerse wêreld uit die Christendom en veral uit die Protestantisme ontstaan het. Menseregte, persoonlike vryheid, godsdiensvryheid, demokratiese regeringstelsels en liberale lewensbeskouings het alles saam met Protestantisme gegroei. Protestantisme word gekenmerk deur die aansienlike afname van die invloed van heilige of gewyde goedere en religieuse misterie in die daaglikse realiteit (Berger, 1990:110-111). Daarom sê Moltmann (1999:198) is Protestantisme ' $n$ godsdiens van vryheid. Hierin is dus bespeurbaar hoe Protestantisme self as 'n historiese, maar steeds bepalende draer van sekularisasie dien.

\subsection{Die uitwerking van sekularisasie}

Die uitwerking van sekularisasie op religie en die kerk word vervolgens bespreek. Dit is opvallend dat dit wat nou as die uitwerking van sekularisasie bespreek word reeds onder die bespreking van die sosiale konstrukte in Suid-Afrika en religieuse konstrukte in die NG Kerk aan die orde gekom het. Dit is 'n aanduiding van die subtiele deurwerking van sekularisasie.

- Fragmentasie en pluralisasie

Die sekulariserende drywer, institusionele differensiasie, het sosiale fragmentasie tot gevolg wat impliseer dat sosiale monopolieë soos godsdiens opgebreek word en dat die speelveld vir die wedywering van 'n veelvoud sosiale idees en oortuigings geopen word (Martin, 2005:20). Fragmentasie loop dus hand aan hand met pluralisasie in die sin dat 'n diversiteit van oortuigings en waardes al meer die strukturerende beginsel van hedendaagse samelewings word (McGuire, 1991:255). Dit hou die probleem van proliferasie in deurdat wyduiteenlopende morele maniere van dink en doen (wat gekenmerk word 
deur kompulsiwiteit) in die samelewing toeneem (Norman, 2003:40,41). Oor hierdie tipe morele klimaat verloor die kerk beheer.

In die Christendom lei hierdie fragmentasie tot groeiende denominasionalisme wat deur kompeterende, godsdienstige oortuigings en 'n mengelmoes van spirituele ervarings gekenmerk word (Avis, 2003:99). Dit destabiliseer die Christelike religieuse front (Taylor, 2007:594). Institusionele stabiliteit word moeilik behou en gevolglik verander historiese kerke (Martin, 2005:21). Godsdienstige aanhanklikheid is ook nie meer 'n gegewe nie en daarom betree godsdienstige instellings 'n bemarkingsituasie waar die instellings self verbruikerskommoditeite word. Vir Avis (2003:87) is 'n goeie voorbeeld die groot afwykende 'industrie' wat binne die wêreldwye, charismatiese konteks 'n evangelie van materiële voorspoed en sukses as 'verbruikerskommoditeit' via digitale- en mediakanale versprei.

\section{- Die ontstaan van 'n geloofwaardigheidskrisis}

Die geloofwaardigheid van godsdiens word deur sekularisasie in gedrang gebring omdat dit die religieuse raamwerke in die moderne samelewing geleidelik uitkalwe (Turner, 2011:140). In 'n sekulêre wêreld word godsdienstige waarhede dikwels getoets aan die beginsels van die rasionele wetenskapskultuur en is die gevolgtrekking dan dat dit nie onveranderlike en onaantasbare waarhede is nie (Shutte, 1992:15). Godsdiens se geloofwaardigheidstruktuur word nie meer sondermeer as vanselfsprekend aanvaar nie (Berger, 1990:153). Dit bring mee dat godsdienstige instellings se vermoë om die massas se oortuigings te vorm, kwyn. Kerklui verloor hulle outoriteit en kan die publiek nie meer dikteer omtrent morele sake nie (Norris \& Ingelhart, 2004:25). Hierdie toedrag tesame met die tolerering van ander sosiale oortuigings en waardes laat nie alleen sekularisasie manifesteer nie, maar bewerk 'n gees van onsekere relativisme (Avis, 2003:68,69). 'n Tolerante en relativistiese gees laat alle waarheid en waardes vloeiend en konteksbepaald word (Kotze, s.a.:72).

In 'n pluralistiese sosiale situasie word godsdiens op 'n sosiaalstrukturele vlak demonopoliseer. Dit word moeiliker om 'n godsdienstige geloofwaardigheidstruktuur in die algemeen in stand te hou of opnuut te konstrueer en daarom bewerkstellig dit nie meer sosiale binding in die gemeenskap as geheel nie (Berger, 1990:156).

- Privatisering van die godsdiens

Fragmentasie en pluralisasie asook die geloofwaardigheidskrisis wat godsdiens moet trotseer, het 'n subjektiverende effek wat die fondasie lê vir die psigolisering en privatisering van die godsdiens. Sekularisasie dwing godsdiens 
(ook die Christelike geloof) na die private sfere van die samelewing, aangesien dit as 'n persoonlike voorkeur geag word (Avis, 2003:76). Sekularisasie laat individuele spiritualiteit van kollektiewe, tradisionele vorms van godsdiens wegskuif (Norris \& Ingelhart, 2004:40). Hierdie private of geïndividualiseerde godsdiens het sinkretistiese trekke omdat dit bestaan uit religieuse goedere vanuit verskillende kerklike en spirituele tradisies wat aangepas word by die gelowige individu se persoonlike sentimente en sy soeke na persoonlike welsyn (Norman, 2003:49). Moraliteit word deesdae op dieselfde wyse gevorm en sodoende kom kollektiewe religieuse en morele waardes onder druk (Avis, 2003:94). Niemandt (2013b:9) meen die krimping van die NG Kerk kan toegeskryf word aan die toenemende individualisering van godsdiens en die feit dat mense 'n onafhanklike lewe kan en wil lei. Sekularisasie en gepaardgaande privatisering veroorsaak dus dat die kerk al meer uitgelewer is aan die wisselvalligheid van private of geïndividualiseerde godsdiens.

- Verandering van die institusionele religieuse ruimte

Die geïnstitusionaliseerde kerk word deur 'n veelvoud van strukturele en sosiale kragte wat deur sekularisasie aangebring word, beïnvloed. Die kerk pas ook by die moderne bewussyn aan sodat dit 'bruikbaar' is vir die moderne denke en handelinge. So vind ons die veranderings ten opsigte van spiritualiteit in die NG Kerk waarna reeds verwys is. Daar is veranderings in die godsdienstige byeenkomste (in die liturgie en die prediking), in die pastoraat en apostolaat wat 'n minder eensydige getuienis verteenwoordig (Dekker, 1997:217). In die NG Kerk word die aanpassings verreken deur die kerk te beskou as 'n ruim huis waar verskillende menings en praktyke op 'n respekvolle en liefdevolle manier hanteer kan word (Oosthuizen, 2012:3). Dit is moeilik om 'n ideale posisie te vind, want daar sal altyd die gevoel wees dat die bekende, godsdienstige identiteit deur aanpassing verswak word (Dekker, 1997:199).

Mense se verhoudinge met die geïnstitusionaliseerde kerk verander ook. Verskillende vlakke van vervreemding is waarneembaar hoewel die vervreemding nie altyd op verminderde geestelikheid dui nie. Nel (2003:21) bevestig dat terwyl die kerk besig is om veld te verloor daar baie mense is wat na God buite die kerk soek! In dié verband kan die onlangse Angus Buchan-fenomeen genoem word. Niemandt (2013b:9) verwys na die verskynsel dat mense hulleself nie meer as 'godsdienstig' beskryf nie, maar wel as 'geestelik'. "Baie mense wat kerklos raak, verkies om hulle spiritualiteit op 'n ander manier uit te leef." (Oosthuizen, 2013:1). Hier kan gedink word aan die Nuwe Hervormingsnetwerk, die Sentrum vir Eietydse Spiritualiteit en Renaissance-gemeentes as voorbeelde van hoe hierdie soeke momentum 
kry (Pienaar, 2010:2). Hierdie ontwikkelings verteenwoordig 'n nuwe soort postgodsdienstige geloof wat sosioloë meen deur die sekularisasieproses self opgeroep word (Dekker, 1997:221).

Die uitwerking van sekularisasie bring vir die kerk enorme uitdagings en vra 'n nuwe benadering tot kerkwees.

\subsection{Kragte teen sekularisasie}

Die vraag is of sekularisasie as sosiale proses onontkombaar of omkeerbaar is. Die volgende is enkele scenario's waarin sekularisasie ondermyn word:

\section{- Godsdienstige vitaliteit}

Sekularisasie is 'n gegewe, maar die kerk is nie hulpeloos as gevolg daarvan nie (Oosthuizen, 2012:3). Desondanks stel mense nog in godsdiens belang, hoewel godsdienstige vitaliteit vandag grootliks op die kantlyn van die samelewing staan. Hierdie vitaliteit kan op verskillende wyses aangewend word om steeds gemeenskappe en samelewings te beïnvloed. Godsdienstige gemeenskappe kan 'n besondere funksie vervul deur draers van deernis vir die hede en hoop vir die toekoms te wees (Avis, 2003:61).

- Globalisasie en re-sakralisasie

Hoewel globalisasie 'n enorme rol speel in die verbreiding van sekularisasie is Avis (2003:62) van mening dat globalisasie inderwaarheid die effek van sekularisasie kan teenwerk met die uitkoms van re-sakralisasie. Die gelykmakende en nominaliserende impak van globalisasie op 'n gemeenskap kan dikwels dien as impuls om spesifieke lokale identiteite te behou. Godsdiens kan hier van onskatbare waarde wees, aangesien verskillende kulture intiem verbind is met hulle tradisionele godsdiens - 'n verbintenis wat bydra tot die belewenis van heelheid in 'n gemeenskap. Die herlewing van godsdiens kan 'n manier wees om 'n ander identiteit te handhaaf (Avis, 2003:64) te midde van die gelykmakende en nominaliserende effek van globalisasie.

\section{- Desekularisasie}

Maclure en Taylor (2011:49-50) wys op 'n ironie omtrent godsdiens in die publieke sfeer. Wanneer publieke instellings en openbare ruimtes as gevolg van sekularisasie van godsdiens gesuiwer word, vind sekere godsdienstige reaksies plaas wat aandring op die behoud van godsdienstige praktyke en simbole. Die reaksies bevat 'n kombinasie van die volgende: 'n groot godsdienstige ywer, die trotsering van die heersende tydsgees en 'n terugkeer na die gesag van godsdienstige oortuigings wat tradisioneel gegeld het (Berger, 
1990:6-7). Moltmann (1999:210) noem fundamentalisme as deel van hierdie desekulariserende beweging. Berger (1990:8) voeg daarby die oplewing in die Evangeliese (Evangelistiese) kerklike tradisie en dan veral in die neoPentekontalisme. Die vraag is egter of die neo-Pentekontalisme met sy klem op persoonlike voorspoed (wat ironies 'n sekulariserende effek het) standhoudend gaan wees. Waar die oplewing van godsdiens in gesekulariseerde samelewings wel plaasvind, beteken dit nie dat godsdiens herstel word tot sy sentrale morele en sosiale orde nie (Germond, 2005:52).

\section{EMPIRIESE TOETSING}

Empiriese navorsing is by 46 gemeentes van die NG Sinode Hoëveld en NG Oostelike Sinode van die NG Kerk onderneem. By wyse van vraelyste is feite en opinies omtrent NG Kerk-lidmate se sosiale en religieuse konstrukte verkry sodat die betekenis en werking van sekularisasie binne die NG Kerk bepaal kan word. Die vrae in die datastel hou verband met 18 verskillende konsepte (afhanklike veranderlikes) onder drie afdelings: Sosiale konstruksie, religieuse konstruksie en sekularisasie. Drie onafhanklike veranderlikes (ouderdom, woongebied en gemeentegrootte) waarop eenrigting-, tweerigting- en drierigting frekwensies uitgevoer is, is gebruik. Eenrigting variansie-analise-modelle (ANOVA = Analysis of variance) is gebou om gemiddelde persepsies ten opsigte van die konsepte te vergelyk. Hiermee was die departement statistiek aan die Universiteit van Pretoria behulpsaam. Weens die beperkte omvang van hierdie artikel word slegs enkele gedagtes gedeel ten opsigte van die uitkomste van die empiriese navorsing.

\section{Onder die afdeling Sosiale konstruksie:}

- Sosiale rë̈fikasie

Die rol van sosiaal-bepaalde, persoonlike betekenissisteme word belangriker in die lewe van NG Kerk-lidmate namate hulle ouer word. Daar is ook 'n groter bewustheid van hoe hierdie betekenissisteme deur die groter sosiale orde geaffekteer word.

\section{- Reaksie op sosiale verandering}

Hoe ouer lidmate van die NG Kerk is, hoe groter is die gevoel van ontwrigting wanneer die sosiale opset waaraan hulle gewoond is, verander en hoe groter is hulle weerstand teen sosiale verandering. Die lewensuitkyke waaraan hulle gewoond is, word moeilik in hulle persoonlike psige opgehef en daarom lei dit daartoe dat hierdie lidmate minder begrip en toleransie vir ander lewensuitkyke toon. 


\section{- Samelewingsvisie: Apartheidskollektivisme}

Ouer lidmate van die NG Kerk in nie-stedelike gebiede is meer geneig om te beleef dat die Afrikaner in die hedendaagse Suid-Afrika na die kantlyn verskuif is. Hierdie groep toon hoër solidariteit met die Afrikanerverlede. Ouer lidmate elders, asook jonger lidmate in nie-stedelike sowel as stedelike omgewings se tevredenheid omtrent die demokratisering van Suid-Afrika verskil van ouer lidmate in nie-stedelike gebiede. Dit neem hierdie groep lidmate ook langer om die geïnternaliseerde apartheidswaardes en -kultuur af te lê.

- Samelewingsvisie: Multikulturele situasie

NG-lidmate in stedelike omgewings toon 'n groter toleransie van die liberale politieke stelsel en kulturele verskeidenheid in Suid-Afrika. Die ouderdomsgroep 15-55 jaar in 'n stedelike omgewing is skynbaar die beste aangepas by die multikulturele situasie. Met lidmate elders woonagtig, ongeag ouderdom, is dit anders gesteld.

- Samelewingsvisie: Westerse individualisme

Die NG Kerk in sy geheel word deur Westerse Individualisme beïnvloed deurdat die idees daarvan diep gewortel is in die psige van NG Kerk-lidmate. Die erkenning van lidmate se individuele uniekheid en regte is vir hulle baie belangrik en daarom is persoonlike vryheid, privaatheid en strewe na voorspoed voorkeur-prioriteite in NG Kerk-lidmate se lewe.

'n Vergelyking tussen apartheidskollektivisme, multikulturele situasie en Westerse individualisme toon an dat Westerse individualisme as samelewingsvisie die grootste invloed in die lewe van NG Kerk-lidmate uitoefen. Dit is veelseggend dat die werking van sekularisasie juis in dié samelewingsvisie die opvallendste is.

\section{Onder die afdeling Religieuse konstruksie:}

- Persoonlike belang van religie

Die belangrikheid van godsdiens vir NG-lidmate se persoonlike lewe neem met ouderdom toe. Dit sluit in 'n toenemende waardering vir die Bybel en die kerk.

Die persoonlike belang van religie het in kleiner gemeentes 'n groter effek as groter gemeentes, waarskynlik omdat kleiner gemeentes se volhoubaarheid meer afhanklik is van sy lidmate se godsdienstige erns en deelname.

- Kollektiewe belang van religie

Die NG Kerk se amptelike gestalte (ingeslote die kollektiewe oortuigings en praktyke asook die taak van geordendes) is vir ouer lidmate van die NG Kerk 
belangriker as vir jonger lidmate. Hulle beleef dit ontstellend dat daar al meer uitgesproke stemme teen geldende geloofswaarhede is en dat daar 'n groot vakuum ten opsigte van sedelike beginsels in die samelewing is. Daarom voel ouer lidmate sterker daaroor dat die amptelike NG Kerk deel behoort te vorm van die samelewing se normatiewe raamwerk.

Die belang van kollektiewe religie is in nie-stedelike gebiede hoër as in stedelike gebiede, waarskynlik omdat die kerk (en die geordende leraar) in niestedelike gebiede nog 'n simboliese en prominente rol vervul.

In die vergelyking van Persoonlike belang van religie met Kollektiewe belang van religie dra eersgenoemde vir NG-lidmate meer gewig. Hoewel die amptelike NG Kerk steeds van belang geag word, kan die swaarder gewig daarop dui dat die private sfeer se persoonlike religie van meer belang is as die kollektiewe, offisiële religie.

- Invloed van konteksbepaalde religie (in die NG Kerk)

Die invloed van konteksbepaalde religie (in NG Kerk) het 'n groter effek op ouer lidmate en korrespondeer dus met die konsep sosiale reïfikasie. Namate NG Kerk-lidmate ouer word, het hulle sosiale konteks 'n toenemende effek op hulle godsdiensbelewenis. Hulle is sensitiewer vir die effek van verandering in hierdie konteks wat 'n gevoel van anomie en selfs geestelike ontreddering kan meebring.

Dié konsep is oor die geheel van die NG Kerk 'n belangrike faktor wat beteken dat die NG Kerk sensitief is vir die konteks waarin dit bestaan, die kompleksiteit daarvan probeer verstaan en uitdagings daaraan verbonde probeer aanspreek.

- Veranderlikheid van religie (in die NG Kerk)

Die uitkomste toon aan dat godsdienstige betekenissisteme in heterogene, stedelike omgewings onder druk is en nie staties bly nie. Net so is dit groter NG-gemeentes wat voortdurend verander omdat dit as heterogene omgewing 'n redelike hoë mate van openheid het ten opsigte van andersoortige aanbiddingstyle en nuwe bedieningspraktyke. NG-lidmate aldaar is ook meer onder die invloed van die sleurkrag van persoonlike oortuigings en andersoortige spiritualiteite en style. Dié toedrag plaas die NG Kerk se gereformeerde identiteit onder druk.

- Pluralisasie van die religie (in die NG Kerk)

NG-gemeentes binne stedelike omgewings vind dit moeiliker om hulle legitimiteit en outoriteit te vestig en te handhaaf as gevolg van kompeterende, 
sosiale en godsdienstige betekenissisteme in hierdie gemeenskappe. Die uitkoms bevestig ook die hoër voorkoms van interne pluralisasie in groter gemeentes van die NG Kerk, soos gesien in die hoë voorkoms van groepspesifieke bedieninge en die verbreiding van verskillende spiritualiteite aangebring deur die subjektiewe inslag van persoonlike behoeftes. Hoe jonger lidmate is, hoe meer verdraagsaam is hulle vir hierdie pluralisasie binne hulle gemeente.

- Spiritualiteit in die NG Kerk

Jonger lidmate van die NG Kerk identifiseer minder met die kerk se gereformeerde identiteit en is meer ontvanklik vir ander spiritualiteitsvorms en godsdienstige oortuigings. Dieselfde gebeur in groter gemeentes van die NG Kerk waar hoë interne pluralisasie die gereformeerde identiteit onder druk plaas. Gereformeerdheid in 'n stedelike omgewing beleef'n groter uitdaging om sy legitimiteit as betekenissisteem in die lewe van lidmate te handhaaf.

- Privatisering van religie

Die uitkoms toon dat NG-lidmate toenemend hulle identiteit in die private sfeer van hulle lewe vind waar persoonlike sentiment en genoegdoening belangrik is. Vir baie lidmate word godsdiens 'n persoonlike aangeleentheid wat tot ' $n$ geïndividualiseerde sisteem ontwikkel. Dit ondermyn gevestigde dogma en kerklike uitsprake. Kerk-georiënteerde godsdiens verloor sodoende sy bindende karakter terwyl lidmate se meelewing toenemend vrywillig word. Dit gebeur in 'n meerdere mate binne stedelike omgewings, waarskynlik omdat lidmate hier al hoe meer geïsoleerd leef.

\section{Onder die afdeling Sekularisasie:}

- Strukturele sekularisasie

NG-lidmate meen dat sosiaal-strukturele prosesse soos liberale demokrasieë en die moderne wetenskap sekularisasie aanhelp. Ouer lidmate beleef die verwydering van religieuse strukture van ander institusionele strukture as nie-wenslik. Dit veroorsaak dat godsdiens nog meer op gelokaliseerde en die private sfere aangewese is.

- Sekularisasie: Vermindering van religie se reikwydte

Hoe ouer die lidmate van die NG Kerk is, hoe meer is hulle daarvan oortuig dat sekularisasie godsdienstige waardes in die samelewing verminder, dat die kerk min effek op openbare opinies het en dat mense vandag toenemend ongeërgd teenoor die tradisionele kerk is. 
Die konsep het ook 'n betekenisvolle impak op groter gemeentes. Groter NG-gemeentes is normaalweg binne stedelike gebiede geleë waar die groter omgewing toenemend ongeërgd staan teenoor die kerk as instelling. Hier verminder die kerk se simboliese en prominente rol algaande. Kerklike beïnvloeding vind grootliks op die kantlyn van die samelewing plaas.

- Sekularisering van die sosiale kultuur

Hoe ouer NG-lidmate is, hoe meer is hulle van mening dat sekularisasie veroorsaak dat mense toenemend oor die lewe nadink sonder om enige godsdienstige interpretasies te gebruik en dat die sosiale kultuur gevolglik gekenmerk word deur die oorwaardering van die stoflike en materiële. Lidmate 15-49 jaar oud huldig hierdie oortuiging in 'n mindere mate.

Ouer lidmate is ook meer onthuts omdat die NG Kerk se religieuse en morele outoriteit in die sosiale kultuur gedevalueer word weens die populêre humanistiese mensbeskouing dat die mens van 'n godsdienstige realiteit se invloed vry gereken word. Lidmate 15-49 jaar oud deel nie hierdie sentiment nie wat aandui dat die religieuse en morele outoriteit van die NG Kerk in die onderdomsgroep onder druk is.

- Sekularisasie: Vermindering van godsdienstigheid

Ouer lidmate van die NG Kerk beleef sekularisasie se negatiewe impak op godsdiens meer akuut as jonger generasies. Hulle is ook meer daartoe geneig om aan te neem dat die belangrikheid van godsdiens in mense se persoonlike lewe afneem weens die feit dat die geïnstitusionaliseerde kerk al minder 'n bron van identiteit in die samelewing is en omdat verbondenheid aan die kerk (NG Kerk) ook toenemend vrywillig is. Tog word ook aangedui dat sekularisasie die samelewing in sy geheel nie van godsdiens ontneem nie. Die individualisering van die godsdiens, dien aan die positiewe kant tog as dryfveer vir die uitlewing van godsdienstige oortuigings asook godsdienstige aksies op hierdie vlak.

- Sekularisering van die persoonlike bewussyn

Die konsep het 'n betekenisvolle effek in klein en groot gemeentes, hoewel die effek groter is by kleiner gemeentes. Die effek van sekularisasie wat veroorsaak dat mense op alternatiewe wyses, anders as net godsdienstig, oor die werklikheid nadink, is groter op die NG Kerk in sy kleiner, nie-stedelike gedaante. Weens die meer prominente rol en betekenis van die kerk aldaar is die effek meer opmerklik as in stedelike gebiede waar die kerk 'n minder prominente rol speel. Die NG Kerk in kleiner, nie-stedelike gestalte beleef ook die gevolglike verbrokkeling van die morele eenheid wat altyd deur die kerk in 
stand gehou is, ook meer intens. Enige verandering in lidmate se godsdienstige erns en deelname is meer opmerklik in kleiner gemeentes.

Ouer lidmate in hierdie gemeentes voel die meeste ontwrig deur die algemene effek van die sekularisering van die persoonlike bewussyn.

- Sekularisasie: Omvorming van religie

NG-lidmate ouer as 55 jaar is die meeste daarvan oortuig dat sekularisasie religie omvorm en dat dit 'n algemene tendens in die kerk is. In die beskrywende statistiek is die privatisering en gevolglike individualisering van die godsdiens die faktore wat hiertoe bydra. NG-lidmate ouer as 55 jaar is daarvan oortuig dat hierdie faktore die gevestigde dogma en praktyke van die NG Kerk destabiliseer en tot algemene onkunde omtrent die dogmas van die Christelike geloof lei. Dit veroorsaak dat persoonlike religie nie meer so afhanklik van die kerk is nie. So neem die kerk 'n veranderende plek in die lewe van lidmate in.

\section{OM VANDAG KERK TE WEES}

Die NG Kerk se resente situasie en konteks - die saeculum - bied bepaalde uitdagings aan die kerk:

\section{Uitdaging 1: Om kerk te wees, is om medeskepper van 'n demokratiese etos te wees}

Suid-Afrika se demokrasie behoort burgerlike vrede, gelyke geleenthede en regte asook 'n kwaliteit lewe vir alle landsburgers te waarborg, maar dit word deur reuse sosiale en politieke dilemmas bedreig. Aangesien die NG Kerk die kompleksiteit en uitdagings van die hedendaagse lewe probeer begryp, behoort dit vir die kerk duidelik te wees dat dit die taak het om sy lidmate te help om 'n gemeenskaplike openbare etos wat die demokrasie sal bevorder, te vestig en te ondersteun. Dít is nodig omdat lidmate se godsdienstige betekenissisteme geaffekteer word deur die groter sosiale orde waarbinne hulle leef. Lidmate moet ook begelei word om hulle eie lewensuitkyke te dekonstrueer en dit aan te pas by die eis dat ons nie net aan onsself sal dink nie, maar ook aan ons naaste.

\section{Uitdaging 2: Om kerk te wees, terwyl godsdiens toenemend in 'n oop sisteem transformeer}

Die NG Kerk verander voortdurend in veral meer heterogene omgewings, soos in groter gemeentes binne stedelike omgewings. Hier kom die NG Kerk 
se gereformeerde identiteit onder druk weens die voorkoms van nuwe tipes godsdienstigheid wat al hoe minder van die offisiële kerk afhanklik is. In die hantering van die uiteenlopende aard van verandering in die kerk moet die kerk 'n 'aanpasbare kerk' word (Thomas Bandy soos gebruik deur Niemandt, 2011:13). Daar behoort'n gemaklikheid met verandering te wees, omdat gemeentes kulturele sisteme is wat op die diepste vlak kan verander. Klaasing (2011:11) maan egter dat verandering nie Bybels-verantwoorde kernwaarhede mag kompromitteer nie, andersins verloor die Christendom (en kerk) sy uniekheid en verdwyn sy waarheidsaansprake. Hierteen moet die NG Kerk op plaaslike gemeentevlak en tot op sy hoogste amptelike vlak waak.

\section{Uitdaging 3: Om kerk te wees, terwyl godsdiens toenemend na die private sfeer verskuif word}

Sekularisasie loop hand-aan-hand met ekspressiewe individualisme en die soeke na selfvervulling. Die kollektiewe geloofspraktyk speel al minder 'n rol in lidmate se persoonlike religie. In die plek daarvan word lidmate se onuitgesproke verwagting al sterker dat die kerk hulle behoefte aan persoonlike welwese sal aanspreek. Ook die NG Kerk moet hierdie uitdaging in sy kerklike bediening aanspreek, want gebeur dit nie, verminder die kerk se invloed in mense se lewe. Daarom moet die kerk op voortgesette wyse lidmate toerus om hulle Christelike oortuigings en roeping prakties uit te leef (Cobb, 1996:202).

Aangesien die kerk se sosiale betekenis verminder moet die NG Kerk ook nuwe patrone van solidariteit vind sodat mense sosiaal kan saamstaan en saamwerk (Vos, 1995:200). Hoewel groeiende privatisme hierdie onderneming van die kerk kan ondermyn, moet dit nie die kerk verhinder om steeds aandag te gee aan die publieke, korporatiewe dimensie van die Christelike geloof nie. Gemeenskaplike waardes en oortuigings moet steeds gepredik en gevestig word (Avis, 2003:12).

\section{Uitdaging 4: Om kerk te wees binne 'n konteks wat skynbaar al hoe minder met God en die kerk tereg kan kom}

Strukturele sekularisasie tesame met die sekularisering van die sosiale kultuur veroorsaak dat godsdienstige waardes en opinies min effek in veral stedelike omgewings en -instellings het. Een kenmerkende gevolg hiervan is dat mense dit skynbaar regkry 'om sonder God klaar te kom' (Gaum, 2011:20). Wanneer dít gebeur, word die openbare terrein gevul met 'n diversiteit van uiteenlopende sekulêre kernoortuigings op alle vlakke van die samelewingsordening. Sosiale ontaarding is die gevolg. Hoewel die kerk se stem hierdeur verdof word, verdwyn dit nie uit die 
samelewing nie en het die kerk die taak om te help skep aan 'n openbare etos met die welwese van gemeenskappe as doelwit. Dit vra toleransie van die kerk, aangesien sodanige etos nie noodwendig enige godsdienstige verwysings sal bevat nie (Maclure \& Taylor, 2011:107). Die algemene behoefte aan menslike sekuriteit en lewensin wat in alle tipe samelewings bestaan, bied vir die kerk (ook die NG Kerk) geleentheid om steeds 'n bydrae te lewer - al geskied dit van die kantlyn af.

\section{Uitdaging 5: Om kerk te wees, is om te help skep aan 'n moderne morele orde}

Sekularisasie ontneem nie die kerk sy sê omtrent die samelewingsordening nie ook nie die morele orde nie. Die liberale staat het die deur vir morele gelykheid en die vryheid tot selfaktualisering geopen. Dit ironie is dat die liberale staat deur die probleem van proliferasie uitgedaag word om morele integriteit te vestig, aangesien dié situasie destruktief vir die samelewing in geheel kan wees (Maclure \& Taylor, 2011:77,92). In aansluiting by uitdagings 1 en 4 word die noodsaaklikheid van'n oorkoepelende, morele raamwerk in 'n gesekulariseerde demokrasie weer eens beklemtoon. Omdat gemeenskaplikheid in Suid-Afrika beperk is, bly die morele orde hier in die algemeen vaag. Gemeenskapsinstelling (ingeslote kerke) behoort dus met erns aan die morele dialoog deel te neem en hulle met die waardes en norms wat gemeenskaplik gevestig moet word, vereenselwig (Chapman, 2004:12-13). Die kerk in die algemeen moet steeds daarna strewe om gemeenskappe op te bou en deur hulle geloofsgemeenskappe waardes binne die samelewing versprei (Chapman, 2004:10-12). Aangesien menseregte al hoe belangriker word, meen Moltmann (1999:117-118) behoort dit 'n beduidende invloed te hê op die vorming van enige morele raamwerk. Menslike solidariteit moet ook uitgebou word om mense aan hulle gemeenskappe te verbind. Hiermee moet die NG Kerk help.

\section{Uitdaging 6: Om opnuut na te dink omtrent die NG Kerk se identiteit}

Daar is genoeg aanduidings dat die NG Kerk steeds oor lewenskragtigheid beskik. Vir die behoud van die kerk se geloofwaardigheid noem Gaum belangrike beginsels wat die NG Kerk ter harte moet neem. Die skrywer sluit hierby aan:

- Dink opnuut oor Jesus en sy opdrag van liefde

Die kerk moet volhou om die uniekheid van Jesus Christus te bely en ook die liefde wat die waarmerk van die ware kerk van Jesus Christus is, te toon (Gaum, 2011:141). Gemeentes wat geloofsgemeenskappe in die ware sin van die woord is, groei (Hanekom, 2010:18). 
- Die kerk is steeds 'n belydende kerk

Gereformeerde kerke se belydenisgrondslag vorm hulle identiteit. Die NG Kerk sal opnuut oor sy belydenisgrondslag en identiteit moet nadink juis omdat denominasionele identiteite onder druk is (Van Rensburg, 2010:21). Dit ís belangrik dat die NG Kerk steeds duidelik sal sê wat dit glo, maar ook wat sy roeping is (Gaum, 2011:153,154).

- Reik verby grense

Verskille onder Christene lei dikwels tot openlike vyandigheid. Die nuwe en die andersoortige waaraan die NG Kerk toenemend blootgestel word, vereis dus gesprek en nadenke (Niemandt, 2013a:7). Vir Christene om mekaar in hulle verskille te ken, moet hulle nader aan mekaar beweeg. Dit is ekumenisiteit: die ontdekking van die ander en die wedersydse aanvaarding van mekaar se andersheid (Moltmann, 1999:203). Die NG Kerk moet hiertoe bereid wees en behoort ook by die ekumeniese kerk aan te sluit sodat dit kan deel aan teologiese agendas op daardie vlak (Naude, 2004:45).

- Aanvaar verandering as 'n gegewe

Dat die NG Kerk verander, is 'n gegewe. Aanvaar dit. Lidmate is redelik oop daarvoor as die bediening dit vereis en solank hulle bekende, godsdienstige betekenissisteme nie daardeur bedreig word nie. Lidmate moet deur verandering begelei word sodat hulle begrip sal hê van die faktore wat veranderings aanbring of andersins tot weerstand daarteen lei.

- Bou die amp van die gelowige uit

Die kerklike lewe word omvorm deur die invloede van geïndividualiseerde godsdiens. In plaas daarvan om daardeur lamgelê te word, behoort die NG Kerk die algemene amp van die gelowige (wat fokus op die belang van persoonlike religie) uit te bou. Dié amp behoort immers tot die wese van die kerk (Gaum, 2011:152). Daarmee word erkenning gegee aan die belangrikheid van lidmate se meelewing ter wille van die voortbestaan van die kerk (Louw, 2010:18).

- Die kerk ís deel van die wêreld waar dit'n profetiese stem het en oor die koninkryk getuig

Ten spyte van sekularisasie in al sy vorms benadruk die gereformeerde beginsel van coram Deo dat alles voor die aangesig van God lewe en daarom behoort geloof ook op die wêreld en die gewone lewe gerig te wees (Gaum, 2011:160). Die NG Kerk mag daarom nie sy getuienisrol versaak nie. Daarom word meer 
en meer gepraat van gemeentes se gestuurdheid - 'n gesindheid wat die kerk help om van sy gemarginaliseerde gevoel ontslae te raak. Kerkleiers moet help om die hedendaagse werklikheid duidelik en feitelik te definieer. Terselfdertyd moet Christene van God se werklikheid waarin hulle glo, getuig (Hanekom, 2011:8) in die vertroue dat die evangelie mense anders sal laat dink, praat en doen (Vos, 1995:200).

\section{Uitdaging 7: Die taak van die teologie}

Om al die uitdagings te verreken, is teologiese besinning uit die aard van die saak nodig. Vir Koopman (2003:6) is'n publieke teologie nodig, omdat die moderne wêreld pragmaties is. Op sosiaal-strukturele vlak meen Koopman (2003:16-17) moet die teologie betrokke wees by die proses van wetgewing, evaluering van wette en die implementering daarvan. Samewerking behoort gevestig te word met die regering op alle vlakke waar strukture krities geëvalueer kan word. Strukturele sekularisasie en institusionele differensiasie kan egter die publieke teologie tot'n blote akademiese oefening reduseer. Ten opsigte van die kollektiewe sosiale bewussyn behoort die publieke teologie 'n bydrae te lewer tot die publieke gesprek omtrent moraliteit deur 'n sosiale raamwerk vir moraliteit te ontwikkel en dit te artikuleer.

Teologiese studie is ook in voortdurende beweging binne 'n altyd-veranderende samelewing. Daarom behoort die teologie die historiese en teenswoordige bewussyn te verreken, want teologiese denke op 'n sekere tydstip is slegs 'n weergawe van die heersende dogma in diekerk op daardie tydstip (Gerrish, 1989:163). Weens pluralisme is daar ook verskeidenheid van interpretasies van basiese Christelike oortuigings en daarom moet die teologie ook ruimte maak vir die konsep "geïntegreerde diversiteit" (Brauer, 1989:206-207). Akademiese teoloë het die taak het om te help vorm aan 'n oorkoepelende konteks waarin die Christelike geloof 'n bydrae kan lewer tot die omvattende verstaan van die realiteit (Cobb, 1996:198).

\section{SLOT}

'n Paar opsommende gedagtes:

- Strukturele sekularisasie verander die posisie van die kerk (ook die NG Kerk) binne moderne gemeenskappe. Geïnstitusionaliseerde godsdiens se reikwydte is minder in stedelike gebiede as in nie-stedelike gebiede.

- Westerse Individualisme se humanistiese mensbeskouing en prioriteite van persoonlike vryheid, privaatheid, selfstandigheid, vryheid van keuse en persoonlike welvaart bied die gronde waarin die sekularisering van die sosiale kultuur vrylik kan tier. 
- Moderniteit en postmoderniteit se klem op die universele kriteria van rasionaliteit het die moderne mens laat ontwikkel in 'n ongebonde, selfstandige individu wat homself vry reken van die invloed van 'n godsdienstige of metafisiese wêreld. Sy eie opinies word die kriteria waarvolgens geleef word. Sodoende word die offisiële kerk al minder 'n bron van persoonlike identiteit.

- Sekularisasie laat religie as verskynsel nie verdwyn nie, maar omvorm dit. Dit dwing godsdiens na die private sfeer waar dit minder afhanklik van kollektiewe geloofspraktyke is. Die sin van godsdiens hang al meer af van die individu se soeke na vervulling en persoonlike sekuriteit. Dit lei tot die verbreiding van 'n veelvoud van geloofsoortuigings en -praktyke wat ook by lidmate van die NG Kerk merkbaar word. Die kragte van privatisering en individualisering van die godsdiens omvorm die bekende religieuse konstrukte en praktyke van die NG Kerk.

\section{BIBLIOGRAFIE}

Avis, P 2003. A church drawing near. Spirituality and mission in a post-Christian culture. London: T\&T Clark International.

Balcomb, A 2001. Evangelicals and democracy in South Africa: helpers or hinderers, another look, another method. Journal of Theology for Southern Africa, 109:3-15, March.

Berger, PL 1990. The sacred canopy. Elements of a sociological theory of religion. New York, NY: Anchor Books.

Brauer, J 1989. A paradigm for theology? Introductory remarks. (In Küng, H \& Tracy, D, eds. Paradigm change in theology - A symposium for the future. New York, NY: The Crossroad Publishing Company. p. 205-211.)

Burger, C 2001. Ons weet aan wie ons behoort. Nuut gedink oor ons gereformeerde tradisie. Wellington: Lux Verbi.BM.

Cady, LE \& Hurd, ES 2010. Comparative Secularisms and the Politics of Modernity: An Introduction. (In Cady, LE \& Hurd, ES, eds. Comparative Secularisms in a Global Age. New York, NY: Palgrave Macmillan. p. 3-24.)

Chapman, MD 2004. Pluralism and moral regeneration: building community in South African perspective. Journal of Theology for Southern Africa, 119:4-18, July. 
Cobb, JB jnr. 1996. The multifaceted future of theology. (In Volf, M, Krieg, C \& Kucharz, T, eds. The future of theology. Grand Rapids, MI: Eerdmans Publishing Co. p. 196-204.)

Czeglédy, AP 2008. A New Christianity for a New South Africa: Charismatic Christians and the Post-Apartheid Order. Journal of Religion in Africa, 38(3):284-311.

Degenaar, J 1974. The changed view of man. Journal of Theology for Southern Africa, 6:50-64, March.

Dekker, G 1997. Godsdienst en samenleving: Inleiding tot de studie van de godsdienstsociologie. $4^{\text {de }}$ druk. Kampen: Uitgeverij Kok.

De Klerk, B \& Van Helden, P 2011. Oorsake van kerkkrimping binne die tradisioneel Afrikaanssprekende gereformeerde kerke in Suid-Afrika. Verbum et Ecclesia, 32(1):1-10.

Durand, J 2002. Ontluisterde wêreld: Die Afrikaner en sy kerk in 'n veranderde SuidAfrika. Wellington: Lux Verbi.BM.

Du Toit, C 1999. The quest for African identity and the concept of nation-building as motives in the reconstruction of South African society. (In Walsh T.G. \& Kaufmann F, eds. Religion and social transformation in South Africa. St Paul, MN: Paragon House. p. 1-23.)

Esterhuyse, WP 2001. Before the next rains: from apartheid to transformation. (In Hofmeyr, JW, Lombaard, CJS \& Maritz, PJ, eds. Perspectives on Christianity: 1948 plus fifty years. Theology, Apartheid and Church: Past, Present and Future). Pretoria. p. 187-200. (Series 5, Volume 1: Institute for Missiological and Ecumenical Research).

Gaum, FM 2011. Fluit-Fluit, die kerk is uit? Wellington: Bybelmedia.

Gergen, KJ 1991. The saturated self: dilemmas of identity in contemporary life. New York, NY: Basic Books.

Germond, P 2004. Sex in a globalizing world: the South African churches and the crisis of sexuality. Journal of Theology for Southern Africa, 119:46-68, July.

Gerrish, B 1989. From 'Dogmatik' to 'Glaubenslehre': A paradigm change in modern theology? (In Küng, H. \& Tracy, D., eds. Paradigm change in theology - A symposium for the future. New York, NY: The Crossroad Publishing Company. p. 161-173.) 
Grundlingh, A 2001. Die Anglo-Boereoorlog in die bewussyn van $20^{\text {ste }}$-eeuse Afrikaners. (In Pretorius, F, red. Verskroeide aarde. Kaapstad: Human \& Rousseau (Edms.) Bpk. p. 242-265.)

Handelinge van die twinstigste vergadering van die NG Sinode Hoëveld van die Nederduitse Gereformeerde Kerk gehou in Alberton. 17-19 April 2012.

Hanekom, B 2010. Nuwe tendense in die NG Kerk. Kerkbode:18 Jun. 4.

Hanekom, B 2011. As 'n kerk hoop verloor. Kerkbode:8 Aug. 5.

Hofmeyr, JW 2002. Die NG Kerk en kerkwees in ons tyd. (In Du Toit, P.R., Hofmeyr, JW, Strauss, PJ \& Van der Merwe, JM 2002. Moeisame pad na vernuwing. Die NG Kerk se pad van isolasie en die soeke na 'n nuwe relevansie 1974-2002. Bloemfontein: Barnabas. p. 1-50.)

Johnstone, RL 1988. Religion in society. A Sociology of Religion. Englewood Cliffs, NJ: Prentice Hall.

Kinghorn, J 1986. Konsolidasie, rasionalisasie en dogmatisering. (In Kinghorn, J., red. Die NG Kerk en Apartheid. Johannesburg: Macmillan Uitgewers (Edms.) Bpk. p. 117-143.)

Klaasing, H 2011. Dan word diversiteit skeefgetrek. Kerkbode:11 Aug. 5.

Kotze, JCG s.a. (sine anno). Die kerk op sy soektog - die verkenning. Kaapstad: NG Kerk-uitgewers.

Koopman, N 2003. Some comments on public theology today. Journal of Theology for Southern Africa, 117:3-19, November.

Louw, L 2010. Het die toekoms 'n kerk? Kerkbode:18 Mei. 21.

Maclure, J \& Taylor, C 2011. Secularism and freedom of conscience. Cambridge MA: Harvard University Press. Martin, D 2005. On secularization: towards a revised general theory. Aldershot: Ashgate.

Mcguire, MD 1991. Religion: The social context. $3^{\text {rd }}$ ed. Belmont, CA: Wadsworth Publishing Company.

Moltmann, J 1999. God for a secular society. The public relevance of theology. Minneapolis, MN: Fortress Press 
Naude, P 2004. Is there a future for scholarship? Reformed theological scholarship in a transforming higher education environment. Journal of Theology for Southern Africa, 119:32-45, July.

Nel, A 2003. Op soek na God ... buite die kerk? Wen weer ontnugterde gelowiges se vertrou. Wellington: Lux Verbi.BM.

Niemandt, N 2011. Aanpasbare kerk. Kruisgewys, 11/3:13 September.

Niemandt, N 2013a. “Ons” en "hulle”: 'n nuwe moontlikheid. Kerkbode:7 Jan. 18.

Niemandt, N 2013b. Die NG Kerk krimp: Waar moet ons die redes soek? Kerkbode:9 Feb. 1.

Norman, ER 2003. Secularisation: sacred values in a secular world. London: Continuum.

Norris, P \& Inglehart, R 2004. Sacred and secular: Religion and Politics Worldwide. Cambridge: Cambridge University Press.

Olivier, AR 2002. Derde era: 1902-1961. (In Hofmeyr G., red. NG Kerk 350 Eenhonderd bakens in die geskiedenis van die Nederduitse Gereformeerde Kerk 1652-2002. Wellington: Lux Verbi.BM. p. 158-159.)

Oosthuizen, J 2012. Kleiner maar ruimer NG Kerk. Kerkbode:3 Mrt. 16.

Oosthuizen, J 2013. Krimpende kerk nie net sleg. Kerkbode:1 Jan. 18.

Pienaar, A 2010. Postmoderne mens wil in eietydse taal nadink oor God. Rapport:2 Des. 12.

Schreuder, N 2002. 1994. Toekomsskok of toekomsvisie? (In Hofmeyr G., red. NG Kerk 350 - Eenhonderd bakens in die geskiedenis van die Nederduitse Gereformeerde Kerk 1652-2002. Wellington: Lux Verbi.BM. p. 226-227.)

Shutte, A 1992. The possibility of faith today. Journal of Theology for Southern Africa, 80:14-23, September.

Smit, DJ 2001. Has there been any change? On the role of the Dutch Reformed Church 1974-1990. Scriptura, 76:119-126.

Steyn, GJ 2006. Die NG Kerk se identiteitskrisis. Deel 2: Huidige bewegings, tendense of mutasies. [E-pos aan:] Kruger, P. (pkkruger@telkomsa.net) Sept. 30.

Taylor, C 2007. A secular age. Cambridge: Harvard University Press. 
Turner, BS 2011. Religion and modern society. Citizenship, Secularisation and the State. Cambridge: Cambridge University Press.

Van der Walt, BJ 1999. Godsdiens en samelewing - Christelike betrokkenheid op die markplein. Potchefstroom: s.n. (Reeks F3: Versamelwerke van die Instituut vir Reformatoriese Studie, 1999:51.)

Van Rensburg, J 2010. Wat is verkeerd met ons belydenisskrifte? Kerkbode:21 Nov. 19.

Vos, CJA 1995. Die hoorder en sy konteks. Skrif en kerk, 16(1):193-205. 